\title{
Formation of the capital structure of companies in the metallurgical industry in the Ural region
}

\author{
Elena Panfilova ${ }^{1,2}$, Alexander Lapin $^{1}$ and Elena Razumovskaia ${ }^{1,2, *}$ \\ ${ }^{1}$ Ural Federal University, Yekaterinburg, Russia \\ ${ }^{2}$ Ural State Economics University, Yekaterinburg, Russia
}

\begin{abstract}
Geopolitical conditions continue to exert a significant influence on the state and development of the Russian economy, along with macro and microeconomic factors. In this regard, the protracted crisis period makes companies of certain industries and regions more and more dependent on external and internal conditions. The article discusses the theoretical and practical aspects of the formation of the structure of the monetary capital of companies in the metallurgical industry under the influence of external and internal factors that form a number of financial risks. The study allows us to understand the nature of the influence of financial risks on the cost of capital of companies in the metallurgical industry of the economy. The article presents a comparative characteristic of the indicators of non-ferrous metallurgy companies, their financial stability, as well as the capital structure. This research will be useful for specialists and managers of specialized companies. When writing the article, the authors relied on research methods: analysis and synthesis, comparison, generalization
\end{abstract}

\section{Introduction}

The development of individual regions is for Russia, with its large territory, the most priority condition for the stability of the entire national economy. The metallurgical industry is the leading industry both in Russia and the world as a whole, since it provides reproductive activity for many other industries. Non-ferrous metallurgy is especially relevant and has a potential for development due to the emergence of the latest technologies in medicine, mechanical engineering, and the aerospace industry.

At the same time, the problem of the influence of factors of the external conjuncture and the internal environment in the nonferrous metallurgy industry due to the complex geopolitical situation and sanctions pressure, which impede the attraction of concessional lending, attraction of investments and the implementation of joint projects with foreign partners, is obvious. This trend has a direct impact on the capital structure of companies and, as a result, on financial stability.

Thus, the issue of studying the topic presented is extremely relevant since the business found itself in a difficult situation, when, on the one hand, the need for raw materials and

\footnotetext{
*Corresponding author: rasumovskaya.pochta@gmail.com
} 
materials is growing, and on the other hand, the emerging financial risks do not fully achieve high financial results of companies.

The aim of the study is to identify factors in the external environment and internal environment that have a direct impact on the formation of the capital structure of companies and, as a consequence, their financial stability.

The empirical basis of the research is the specialized normative reference materials, as well as scientific research and educational literature of foreign and Russian authors. In terms of studying the theoretical and practical provisions of the formation of the structure of money capital in this study, the works of such authors as: J. Williams, W. Sharp, S. Myers, A. Damodaran, J. Van Horn, I. A. Blank, E. S. Stoyanova, A. D. Sheremet and others.

The basis for the study of financial risks was the works of the following foreign and domestic authors: M.L. Arnaboldi and I. Enterprise, R. Pellissier, M.R. Salvador and L.F. Salinas Casanova, A. Zh. Abdenov, P.N. Afonin, T.A. Azimov and L.Yu. Beznoschuk, A.I. Afonichkin, V.M. Granaturov, K. Yu. Bagratuni, P.N. Brusov and T.V. Filatova, A.V. Vorontsovsky, O.A. Firsova and others.

The formation of the optimal structure of money capital as a factor influencing the financial stability of a company under the influence of financial risks as a manifestation of the external conjuncture and internal environment has not received proper development in the scientific literature. To a greater extent, the fundamental works affecting the formation of the capital structure, the choice of a policy for managing money capital in conditions of ineffective management are noted.

The scientific contribution of the authors is the development of theoretical provisions and the development of practical recommendations in the field of managing a company's money capital as a factor affecting financial stability as a result of the manifestation of financial risks.

\section{Research methodology}

The goal of any company in a highly competitive environment is to reduce costs and maximize profits. However, in the commodity market, competition is not determined by the price of the commodity, but by the company's ownership share in a particular commodity segment. Since prices are formed on world commodity exchanges, the factor of price competition is excluded, but at the same time the prices formed on the exchange have a direct impact on the quality and, accordingly, the cost of the company's capital, its financial stability. Thus, it should be borne in mind that the implementation of the company's economic activities is due to the specifics of the core business and is subject to the manifestation of risks as a result of the influence of environmental factors.

Note that from the point of view of etymology, the concept of "risk" has Italian roots of origin, and the semantics of the word is defined as a danger or a foreseeable obstacle [1].

In sociology, the term "risk" denotes a possible danger and situational characteristic of an activity, consisting in the uncertainty of its outcome and possible adverse consequences in the event of its failure [2].

In the interpretation of the Russian researcher Baldin $\mathrm{KV}$, in world practice, "risk" is something that is a consequence of uncertainty and can lead to losses or additional opportunities for an organization [3].

In general, financial risk is the essence of making an alternative decision, the result of this choice and the degree of its justification from the point of view of achieving the desired, predetermined result, subject to the likelihood of losses (financial losses) [4].

Financial risks are dual in nature, which is why they belong to speculative risks, for them both positive and negative results are possible. Their feature is the likelihood of damage occurring as a result of such operations, which by their nature are risky [5]. 
Financial Risk - is the risk due to the structure of sources of funds. In this case, we are no longer talking about the riskiness of capital investment in certain assets, but about the riskiness of the policy in relation to the expediency of attracting certain sources of financing for the company's activities [6].

When classifying financial risks, it is customary to divide them into four types:

- risks associated with the purchasing power of money;

- risks associated with capital investments (investment

risks);

- risks associated with changes in demand for the company's products;

- risks associated with attracting borrowed funds as

source of funding [8].

Thus, it should be argued that at present, in scientific Russian and foreign publications of the literature, well-established theoretical and practical provisions have been formed regarding the financial risks of companies, which make it possible to effectively resist risks in conditions of increased turbulence of the external environment and instability of internal factors.

\section{Research results}

Corporations and large enterprises, including the industry under study, disclose information about their financial position and non-financial capital in integrated reports [9]. In this regard, it seems possible to analyze the structure of money capital, as well as to determine the financial stability and key performance indicators of companies in the nonferrous metallurgy sector. The performed analysis will allow to determine the correlation dependence between the capital structure, financial stability and identify the factors influencing the revealed trend for the analyzed period (Table 1).

Table 1. Dynamics and structure of monetary capital of JSC «URALELEKTROMED» 2014-2019, thousand rubles. [10]

\begin{tabular}{|l|c|c|c|c|c|c|}
\hline \multicolumn{1}{|c|}{ Indicator } & $\mathbf{2 0 1 4}$ & $\mathbf{2 0 1 5}$ & $\mathbf{2 0 1 6}$ & $\mathbf{2 0 1 7}$ & $\mathbf{2 0 1 8}$ & 2019 \\
\hline Equity & 26116 & 28959 & 28632 & 27932 & 27125 & 27334 \\
& 264 & 074 & 792 & 455 & 394 & 048 \\
\hline $\begin{array}{l}\text { Long-term loans } \\
\text { and borrowings }\end{array}$ & 4394 & 3888 & 2972 & 6018 & 5544 & 4516 \\
& 251 & 513 & 395 & 225 & 775 & 425 \\
\hline $\begin{array}{l}\text { Short-term loans } \\
\text { and borrowings }\end{array}$ & 4107 & 5197 & 8201 & 7938 & 12227 & 17795 \\
& 323 & 381 & 968 & 591 & 400 & 562 \\
\hline Total & 34617 & 38044 & 39807 & 41889 & 44897 & 49646 \\
& 838 & 968 & 155 & 271 & 569 & 035 \\
\hline D/(D+E) & 0,25 & 0,24 & 0,28 & 0,33 & 0,40 & 0,45 \\
\hline
\end{tabular}

The data in Table 1 indicate an increase in borrowed capital by URALELEKTROMED JSC in the overall structure against the background of a decrease in the share of its own sources of financing, which indicates a decrease in the company's financial stability (Fig. 1, Table 4). 


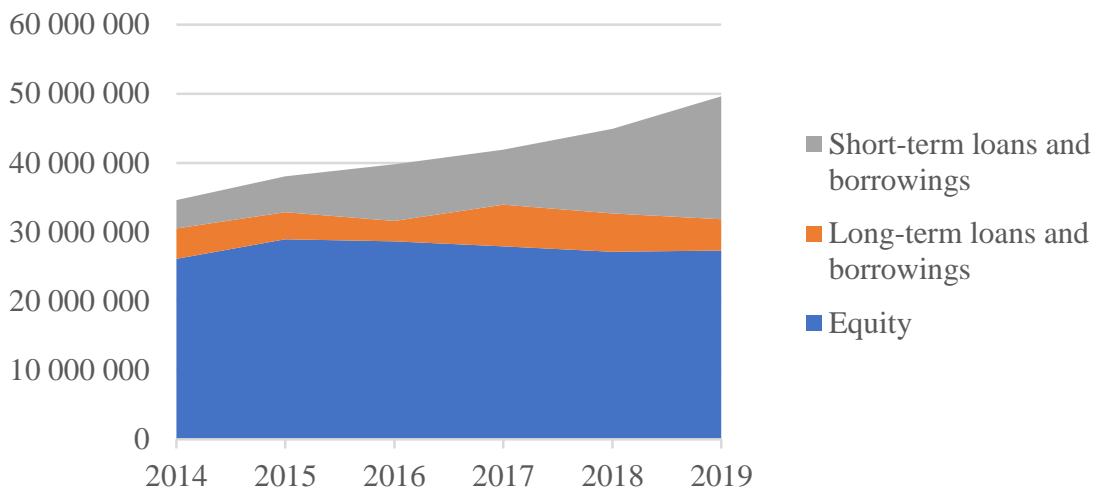

Fig. 1. Dynamics and structure of URALELEKTROMED money capital in 2014-2019, thousand rubles. [10]

Table 2. Dynamics and structure of money capital of JSC ALEXANDRINSKAYA GRK 2014-2019, thousand rubles. [2]

\begin{tabular}{|l|c|c|c|c|c|c|}
\hline Indicator & $\mathbf{2 0 1 4}$ & $\mathbf{2 0 1 5}$ & $\mathbf{2 0 1 6}$ & $\mathbf{2 0 1 7}$ & $\mathbf{2 0 1 8}$ & 2019 \\
\hline Equity & 259307 & 520602 & 1140590 & 1355564 & 1378544 & 2117094 \\
\hline $\begin{array}{l}\text { Long-term } \\
\text { loans and } \\
\text { borrowings }\end{array}$ & 377828 & 5366812 & 4126214 & 3960284 & 698417 & 2183211 \\
\hline $\begin{array}{l}\text { Short-term } \\
\text { loans and } \\
\text { borrowings }\end{array}$ & 5765680 & 531554 & 511822 & 379496 & 3443788 & 1893047 \\
\hline Total & 6402815 & 6418968 & 5778626 & 5695344 & 5520749 & 6193352 \\
\hline D/(D+E) & 0,9 & 0,08 & 0,09 & 0,07 & 0,62 & 0,31 \\
\hline
\end{tabular}

The analysis of the capital structure of JSC "ALEXANDRINSKAYA" showed an increase in the share of equity capital in the total structure of money capital, however, according to the results of the analysis, the company cannot be considered financially stable, since this indicator is 0.6 at a rate of $0.8-0.9$ (Fig. 2, tab. four).

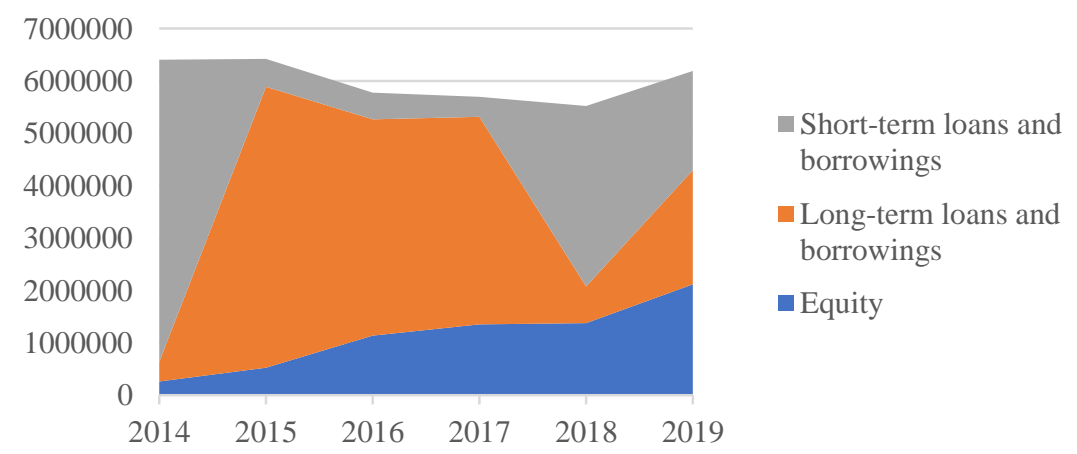

Fig. 2. Dynamics and structure of money capital of JSC "ALEXANDRINSKAYA GRK" 20142019, thousand rubles. [12]

Table 3. Dynamics and structure of monetary capital of JSC KOLSKAYA MMC 2014 - 2019, thousand rubles [14] 


\begin{tabular}{|l|c|c|c|c|c|c|}
\hline \multicolumn{1}{|c|}{ Indicator } & $\mathbf{2 0 1 4}$ & $\mathbf{2 0 1 5}$ & $\mathbf{2 0 1 6}$ & $\mathbf{2 0 1 7}$ & $\mathbf{2 0 1 8}$ & $\mathbf{2 0 1 9}$ \\
\hline Equity & 68668026 & 59483499 & 55748050 & 58860485 & 77286157 & 539860 \\
\hline $\begin{array}{l}\text { Long-term } \\
\text { loans and } \\
\text { borrowings }\end{array}$ & 1960764 & 3037910 & 2702843 & 2975803 & 3786622 & 15121688 \\
\hline $\begin{array}{l}\text { Short-term } \\
\text { loans and } \\
\text { borrowings }\end{array}$ & 5454310 & 9432349 & 13639750 & 14680021 & 14627939 & 281779942 \\
\hline Total & 76083100 & 71953758 & 72090643 & 76516309 & 95700718 & 297441490 \\
\hline D/(D+E) & 0,08 & 0,14 & 0,2 & 0,24 & 0,17 & 1,05 \\
\hline
\end{tabular}

The structure of the monetary capital of JSC KOLSKAYA MMC is characterized by a significant increase in borrowed sources of financing in terms of long-term lending, obviously attracted for the implementation of large projects, and short-term for the purpose of implementing current activities. The analysis of financial stability also showed negative dynamics, which was influenced by the growth of debt financing sources. (fig. 3, table. 4).

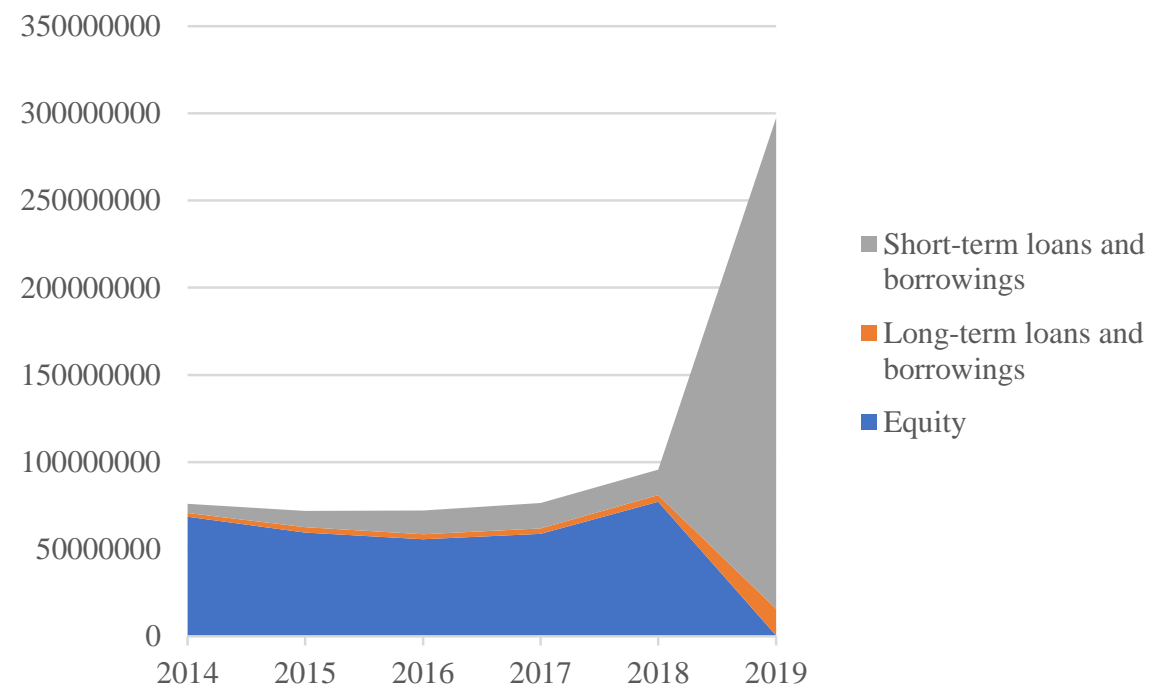

Fig.3. Dynamics and structure of monetary capital of KOLSKAYA MMC JSC in 2014-2019, thousand rubles. [14]

Table 4. Dynamics of financial stability of metallurgical companies and other key financial indicators, 2014-2019 [12-17]

\begin{tabular}{|c|c|c|c|c|c|c|}
\hline Company & 2014 & 2015 & 2016 & 2017 & 2018 & 2019 \\
\hline \multicolumn{7}{|c|}{ Financial stability (standard 0,8-0,9) } \\
\hline $\begin{array}{l}\text { "URALELEKTROMED" } \\
\text { (JSC "UMMC") }\end{array}$ & 0,88 & 0,86 & 0,79 & 0,81 & 0,73 & 0,64 \\
\hline $\begin{array}{l}\text { JSC "Alexandrinskaya } \\
\text { GRK" (JSC "RMK") }\end{array}$ & 0,10 & 0,92 & 0,91 & 0,93 & 0,38 & 0,69 \\
\hline $\begin{array}{l}\text { JSC Kola MMC (PJSC } \\
\text { MMC Norilsk Nickel) }\end{array}$ & 0,95 & 0,91 & 0,84 & 0,78 & 0,88 & 0,06 \\
\hline \multicolumn{7}{|c|}{ Current liquidity ratio (standard $>2$ ) } \\
\hline
\end{tabular}




\begin{tabular}{|c|c|c|c|c|c|c|}
\hline $\begin{array}{l}\text { "URALELEKTROMED" } \\
\text { (JSC "UMMC") }\end{array}$ & 3,74 & 3,1 & 1,78 & 1,68 & 1,26 & 1,11 \\
\hline $\begin{array}{l}\text { JSC "Alexandrinskaya } \\
\text { GRK" (JSC "RMK") }\end{array}$ & 0,12 & 0,24 & 1,05 & 1,8 & 0,18 & 0,90 \\
\hline $\begin{array}{l}\text { JSC Kola MMC (PJSC } \\
\text { MMC Norilsk Nickel) }\end{array}$ & 12,53 & 5,13 & 2,88 & 5,29 & 2,61 & 0,80 \\
\hline \multicolumn{7}{|c|}{ Financial independence ratio $($ standard $0,55-0,7)$} \\
\hline $\begin{array}{l}\text { "URALELEKTROMED" } \\
\text { (JSC "UMMC") }\end{array}$ & 0,75 & 0,76 & 0,72 & 0,67 & 0,6 & 0,55 \\
\hline $\begin{array}{l}\text { JSC "Alexandrinskaya } \\
\text { GRK" (JSC "RMK") }\end{array}$ & $-8,24$ & $-7,92$ & 0,2 & 0,24 & 0,25 & 0,34 \\
\hline $\begin{array}{l}\text { JSC Kola MMC (PJSC } \\
\text { MMC Norilsk Nickel) }\end{array}$ & 0,93 & 0,86 & 0,80 & 0,77 & 0,84 & 0,00 \\
\hline \multicolumn{7}{|c|}{$\begin{array}{l}\text { The ratio of the provision of working capital with its own sources of financing } \\
\text { (standard } \geq 0,1)\end{array}$} \\
\hline $\begin{array}{l}\text { "URALELEKTROMED" } \\
\text { (JSC "UMMC") }\end{array}$ & 0,45 & 0,44 & 0,23 & $-0,05$ & $-0,16$ & $-0,13$ \\
\hline $\begin{array}{l}\text { JSC "Alexandrinskaya } \\
\text { GRK" (JSC "RMK") }\end{array}$ & $-8,24$ & $-7,92$ & $-7,62$ & $-5,35$ & $-5,79$ & $-1,38$ \\
\hline $\begin{array}{l}\text { JSC Kola MMC (PJSC } \\
\text { MMC Norilsk Nickel) }\end{array}$ & 0,88 & 0,71 & 0,57 & 0,13 & 0,48 & $-0,33$ \\
\hline \multicolumn{7}{|c|}{ Return on sales, $\%($ standard $>8 \%)$} \\
\hline $\begin{array}{l}\text { "URALELEKTROMED" } \\
\text { (JSC "UMMC") }\end{array}$ & 7,7 & 18,4 & 9,2 & 7,5 & 3,7 & 1,6 \\
\hline $\begin{array}{l}\text { JSC "Alexandrinskaya } \\
\text { GRK" (JSC "RMK") }\end{array}$ & 22,8 & 30 & 32,1 & 23,1 & 35,6 & 32,2 \\
\hline $\begin{array}{l}\text { JSC Kola MMC (PJSC } \\
\text { MMC Norilsk Nickel) }\end{array}$ & 0,26 & 0,26 & 0,12 & 0,61 & 0,12 & $-0,05$ \\
\hline \multicolumn{7}{|c|}{ Return on assets, $\%$ (standard $>3 \%)$} \\
\hline $\begin{array}{l}\text { "URALELEKTROMED" } \\
\text { (JSC "UMMC") }\end{array}$ & $-0,31$ & 7,47 & 5,46 & $-1,79$ & 3,12 & 0,40 \\
\hline $\begin{array}{l}\text { JSC "Alexandrinskaya } \\
\text { GRK" (JSC "RMK") }\end{array}$ & 1,07 & 4,07 & 10,73 & 9,21 & 5,13 & 15,00 \\
\hline $\begin{array}{l}\text { JSC Kola MMC (PJSC } \\
\text { MMC Norilsk Nickel) }\end{array}$ & 0,15 & 0,18 & 0,08 & 0,04 & 0,07 & $-0,03$ \\
\hline
\end{tabular}

In the analyzed period, a number of external and internal factors influenced the structure and dynamics of money capital, as well as the financial stability of the companies under study:

External:

- The conjuncture of the financial market and the level of interest rates;

-Trends in the development of world capital markets;

- Macroeconomic situation in the country;

- four. . the procedure and norms of depreciation deductions established by the state;

- tax policy of the state, affecting the level of tax burden and, accordingly, the amount of net profit;

- budgetary policy, which determines the priority sectors for budget financing, its conditions and the amount of funds;

- monetary and credit (including foreign exchange) policy of the state, regulating inflation, setting the price of money, quotations of foreign currencies to the national one, conditions for attracting credit resources from non-residents, etc.;

- investment climate of the country;

- cost of borrowed sources; 
- conjuncture of the internal and external commodity market.

Internal:

- phase of the company's life cycle;

- industry specific features;

- the organizational and legal form of activity, enshrined in the constituent documents of the legal entity, which determines the conditions for the formation of the authorized capital and the distribution of profits, incl. clean;

- The scope of the activity;

- Asset structure;

- Industry specifics of operating activities;

The level of concentration of equity capital;

- The level of risk (operating, investment, financial activity);

- Conditions for the formation and distribution of profits;

- Level and dynamics of operating profitability, and return on equity;

- The rate of increase in the volume of sales of products;

- The size of the consolidated cash flow and its distribution over time;

- The liquidity of the organization's assets;

The degree of utilization of production facilities;

- -The level of the company's creditworthiness, determined by its current financial condition;

- relationship between owners and managers, division of powers between them;

- the level of professional qualifications of managers;

- dividend policy;

- publicity of the company;

- long term viability;

- the possibility of providing guarantees to investors, etc.

The presented external and internal factors have a direct impact on the manifestation of financial risks, which in turn have a significant impact on the structure of money capital, financial stability and, ultimately, on the value of the company as a whole.

\section{The discussion of the results}

The results of the analysis carried out by the authors presented in the study indicate the dependence of the structure of the monetary capital of metallurgical companies in the Ural region on the factors of the external conjuncture and the internal macroeconomic environment. Analysis of the array of analytical data in dynamics for the period of geopolitical tension (from 2014 to 2019) made it possible to substantiate the existence of a correlation dependence of the structure and cost of monetary capital of Russian metallurgical enterprises on market volatility, which neither the enterprises themselves nor the Russian government can influence. This circumstance reveals the importance of non-financial conditions on the state of the national economy of the Russian Federation as a transformation of the conjuncture into financial risks. In this regard, the position of the authors correlates with the opinion that financial risks are connected with the likelihood of disruption of financial flows planned by companies [7]. Of course, financial risks are associated, first of all, with the general economic stability in the country: the level of inflation, the sufficiency of budgetary funding where it is provided, and also, as the authors of this study managed to show, with political and geopolitical conditions. In this regard, many scientists believe [4, 5] that assessing the stability of financial flows that determine the structure of companies' money capital and forecasting its value for periods of external economic shocks is absolutely necessary, since it allows to envisage measures to reduce potential risks. 


\section{Conclusion}

The study presents the factors of influence of the external conjuncture and the internal environment that provoke financial risks in the formation of the monetary capital of metallurgical companies and affect their financial stability. The combination of these factors ultimately determines the degree of stability and the rate of development of the industrial regions of Russia, among which the Urals historically occupy a special place.

\section{References}

1. E.V. Ryzhkova, Socio-economic phenomena and processes, 2 (2015)

2. Yu. E. Slepukhina, Risk management in financial markets. (EBS ASV, 2015)

3. K.V. Baldin, Risk management (Eksmo, 2013).

4. E.A. Terekhova, Electron, 100, 69583 (2016)

5. K.Yu. Bagratuni, M.V. Danilina, Risks: Analysis and Assessment (RUSAYNS, 2016)

6. V.G. Belolipetskiy, Financial management. (KNORUS, 2016)

7. V.A. Antonets, I.B. Poor, Innovation management (Yurayt Publishing House, 2019)

8. N.A. Kazakova Analysis of financial statements. Consolidated business (Yurayt Publishing House, 2019)

9. M.A. Camilleri, Corporate communications, 23(4), 567 (2018)

10. Balance sheet of Uralelectromed JSC for 2017-2019, JSC "Uralelectromed"

11. Statement of cash flows of JSC "Uralelectromed" for 2017-2019, JSC "Uralelectromed"

12. Balance sheet of ALEXANDRINSKAYA GRK JSC for 2017-2019, JSC "ALEXANDRINSKAYA GRK"

13. Statement of cash flows of Uralelectromed JSC for 2017-2019, JSC "ALEXANDRINSKAYA GRK"

14. Balance sheet of Kolskaya GMK JSC for 2017-2019, JSC KOLSKAYA MMC

15. Cash flow statement of KOLSKAYA MMC JSC for 2017-2019, JSC "KOLSKAYA MMC"

16. F. Modigliani,The American Economic Review, 48(3), 261 (1958)

17. J. Reimann, IEEE ACCESS, 7,70891 (2019). 